\title{
Procedural Law in the Merchant of Venice
}

\author{
Tatevik S. Karapetyan* \\ PhD Candidate, Post doctorate researcher, Foundation of Giorgio Cini Onlus (Venice), the Head of the \\ Department of Humanitarian Subjects, Associate Professor, the University of Traditional Medicine, Armenia. \\ *Corresponding Authors: Tatevik S. Karapetyan, PhD Candidate, Post doctorate researcher, \\ Foundation of Giorgio Cini Onlus (Venice), the Head of the Department of Humanitarian Subjects, \\ Associate Professor, the University of Traditional Medicine, Armenia.
}

\begin{abstract}
The Merchant of Venice is the most prominent work in terms of presenting foreign characters, different religions and groups in the World Literature. Being a tax evasion Jew, Shylock hates Antonio for lending money without interests. During this period history states that Jews survived in different countries on behalf of lending money for interest, especially in Venice. As the analysis will be in line with the Venetian reality, the aim of the current article is to discuss such legal issues as elements of criminal law, the trial scene that shifts from civil law into criminal law on the basis of comparative law. It involves the problems of prejudice, stereotypes and the oppression of "outsiders," as well as legal issues that existed during Renaissance period in Venice.
\end{abstract}

Keywords: Civil law, criminal law, comparative law, civil and criminal procedural law, equity, morality.

Acknowledgements: I respect and thank the Government of the Republic of Italy, for providing me an opportunity to work on the project "Civil and Criminal Procedures in the Merchant of Venice" in Foundation of Giorgio Cini Onlus (Venice). I am extremely thankful to Professor E. Palandri for providing such a nice support and guidance.

\section{INTRODUCTION}

Christian identity is distinguished by authority in The Merchant of Venice, and specifically in the court scene. In the play Christians have power over Jews and accordingly it leads to destruction at the end of the play to a Jew merchant called Shylock. In fact, Shylock tries to defeat the Christian merchant in the court scene, but unexpectedly, he is defeated, as the trial scene is, in truth, two trials linked together; first a kind of civil discourse, financial when the Jew who had lent his money for interest, wants the fulfillment of the bond. And then when things are clear and it seems that everything goes smoothly and suddenly, as trials are generally unpredictable, the civil trial shifts into a criminal procedure where it is based on prediction of the late scene and where the roles change; the plaintiff becomes accused and is being prosecuted and the defendant becomes a victim. The trial turns from civil into criminal when Shylock forfeits the bond.

This article will be examined from the viewpoint of Venetian reality, as the author is inclined to the statement that Shakespeare might have been in Venice and he had had decent knowledge of Venetian social, legal and economical situation during this period. A huge material has been examined concerning to the legal system of Venice which will be presented in the literature review.

\section{LITERATURE REVIEW}

Guido Ruggiero stated that while much of the rest of Europe was still under the rule of the households of hereditary kings or local nobles, Venice lived and traded under a rule of written law interpreted by elected councils and judges and enforced by an elaborate bureaucracy (Ruggiero 1978:2).

The social defense for a merchant elite system was especially important for protecting the monopoly of power and for providing a climate of peace and stability essential for trade. In the fourteenth century this system was considerably enlarged and strengthened with police patrols eventually reaching a proportion of one patroller to every 250 inhabitants. At the same time, much of the judicial system was streamlined and rationalized (Ruggiero 1978:2). 
The instance on the amateur status of the judges gave Venetian justice a peculiar character. Firstly, in contrast to other Italian states, Roman law was excluded as a source of authority in Venice. The Tuscan ambassador noted how "the lords of Venice are accustomed to judge both civil and criminal cases according to their own laws, and they scorn those of the Empire; if any advocate pleading a case cites a Roman law, they make fun of him' (Shaw 2006:13).

Venetian judges claimed the authority to transcend the law, judging according to conscience rather than science. As the Tuscan ambassador went on to say; "They are so haughty and arrogant as to believe that their decisions are more just, correct and godly than those of anybody else. They are not moved to judge by reason, but only by a kind of probity (per una certa honesta'). This is not, as it ought to be governed by rational principles, but simply follows their own indication, whatever this may be (Pullan 2002: 562).

Venetian legal documents are in fact remarkable for their lack of reference to jurisprudence or learned opinion. Sophisticated legal arguments were likely to have little appeal compared to an informal approach based on the simple facts of the case. A further peculiarity of Venetian justice compared to standard Italian practice was the fact that the parties and their advocates presented their case orally at the final hearing, a tradition celebrated by Carlo Goldoni, who was a venetian advocate (Vianello 1991: 347).

In the Early Renaissance, custom and law were so intertwined on a day-to-day basis that it was virtually impossible to separate them. Contemporaries did make progress in distinguishing the two, at least on the theoretical level, but their major obstacle in practice was the technological problem of keeping track of the quantity of legislation being passed by the growing number of councils having legislative responsibilities, in the complex governments of the period (Ruggiero 1978:2).

This particularly suited the amateur status of the judges, who would have found the emotive and colorful language of these debates, far more accessible than the dry legalese of the written procedure used elsewhere. This can also be seen in Alberto Bologetti's comment that Venetian advocates "attempt to win over their hearers with flights of rhetoric better suited to the stage" (Chambers and Pullan 2001:102-3).

As Sir Dudley Carleton stated in 1612: "Whereas other governments are ruled by laws the Venetian hath little other than reason of state to which they doe resort in all occasions as that which gives law to all other laws." (Chambers and Pullan 2001:30).

Rhetorical rather than legalistic pleas were designed to appeal to the conscience of the judges to the heart rather than the head, giving Venetian justice a sample, empirical and pragmatic character. In this regard even the Venetian statutes were not always treated with the greatest respect. Rather than the written law, ultimate authority was supposed to lie in the arbitrium of the patriciate, a concept that expressed their unlimited faculty to determine how the law should be applied in any given case (Cozzi 1982: 81).

Alberto Bolognetti noted; " The Venetians make extensive use of discretion [arbitrium] for they are bound by no laws but their own which are very general and compared with others, few in number (Chambers and Pullan 2001:102-3).

The resistance to technical legal argument meant that Venetian justice was based in equity rather than law. As the ambassador of Parma stated in 1590, the Venetians believed "one should not aim at what the laws say, but what a certain equity and natural reason dictate" (Cozzi 1984: 536).

Bodin wrote - law without equity is like a body without a soul, seeing that the law can only lay down general rules, while equity is dependent on circumstances of particular cases. Bodin saw Venetian justice as achieving this "harmonic" blend of rigidity and flexibility and this concept plays a central law in the concluding chapters of his Six Books (Bodin 2009: Ch. 6.764).

The historian Cozzi similarly praised Venetian justice in terms of its flexibility and ability to adapt to human needs (Cozzi 1973: 95).

\footnotetext{
1 "Bisogna mirare non a cio`che dicono le leggi, ma bene a quello che detta una certa equita`e ragione natural”.
} 
To some extent therefore, Venetian justice was distinct from standard Italian and European practice due to its close adherence to the principle of equity. This attachment can ultimately be related to the political order of this aristocratic republic, since its emphasis on moral conscience rather than legal reasoning was particularly appealing to amateur judges aimed with a strong self belief in their innate capacity for justice (Shaw 2006:18).

Raising other comparable questions, the law in Shakespeare has often appeared to be a series of pretexts designed to test the wit of audiences, much as the moots rehearsed for students at the Inns of Court were intended to instruct them in fashioning artful argument (Cunningham 2002: 230).

Thomas C. Bilello, a practicing attorney, opens his interpretation of the court's judgment in the play by observing that Portia fraudulently assumes judicial authority; she is neither a lawyer nor a judge by training or license. Indeed, her interest in punishing Shylock forestalls the kind of unbiased justice Fortes cue had celebrated. Equity, a concept designed to match the letter of the law to the situation it is supposed to address, is not a subject that the play represents. English equity courts provided relief to debtors faced with rigorous rulings in common law courts, and there was a precedent for deferring payment of a debt in Umfraville v. Lonstede, a case decided in the fourteenth century. But Portia and the Venetian court do not consider the remedy in Umfraville and rather support Shylock's demand for payment of the full penalty - a demand that then renders Shylock a criminal within the Venetian state under the alien statute. By comparison to the rulings of English equity courts, which took account of particular hardships, Bilello shows that Portia's justice is little better than a sophisticated form of revenge and the court itself a forum for vengeance (Cunningham 2002: 12).

Posner, while acknowledging that she is an "imposter" with "an undisclosed interest in the outcome of the trial," nevertheless refers to Portia in almost reverent tones as one who applies the law with "sensitivity and tact" so that its spirit is not sacrificed to its letter (Posner 2009:107). He recognizes that "no equitable principles actually inform" the action in the play. Yet he (like many others) seems too willing to discount the fatally compromised position held by Portia qua judge (Posner 2009:110).

Blanchard discusses the distinctions between justice, mercy, love, and law in which she notices that Shylock suffers from inconstancy. In other words, Shylock is seen as uncomfortable for love, mercy or justice. 'In using Shylock to contrast Hebrew rigidity with Christian adaptability, Shakespeare conveys that everyone proves inconstant sooner or later, and thus all must learn to favor love over law, mercy over method, and effort over effect' (Blanchard 2009: 218).

However, Shylock is depicted as a "scapegoat" by Deng and Wu. This characterization leads Deng and $\mathrm{Wu}$ to hold that Shylock defends the ruling class's ideology which makes them feel that greedy people may suffer unfair treatment. They see that Shylock is a victim of the racial prejudices. So, it is clear that these two authors believe that Shakespeare's description of Shylock is merely a picture of his time. However, it is difficult to stand with or against this idea since some actions in the play prove that Shylock is not only a victim, but also is a villain. For example, Shylock's insistence on the literal implementation of the bond could be a clear support for his villainy (Deng, W., \& Wu, Y. 2013:16241629).

O. Hood Phillips, relating how Sir Frederick Pollock had decided Shylock's case - "Declare the bond void at law, involving as it does consent to be maimed. (There is no question of equity in the technical sense.) Judgment for the plaintiff for 3000 ducats, and interest at the current rate, as on a simple contract debt" - speculates on what Venetian law might have required of the debtor Antonio, allowing, as it did, for forfeiture of bodily parts were the terms of a contract not met (Elton 2000:105-107).

According to Keeton, Portia carefully lays a surer foundation for Antonio's defence than that offered by the more startling prohibition against shedding a drop of blood: 'Had she raised the question of the "drop of blood" earlier, this defence [based on criminal attempt] would have been inoperative otherwise the Duke would have recollected the same law and stopped the trial. To bring an action on the bond is not a criminal attempt - the action is too remote from the final consequence that is, the removal of the pound of flesh, and Antonio's ensuing death. But Shylock, having obtained a decision on the effect of the bond, has been earnestly whetting his knife, and has actually been on the point of making an incision when Portia stopped him. This is clearly a criminal attempt, and as such a felony. At this date all felonies were punishable by death and forfeiture of the goods of the deceased. Portia, by consummate skill, has caught Shylock at last in his own net; the theatre rocks with applause' (Keeton1967:145). 
In legal terms one might say that Portia personifies the spirit of equity - the prudent recognition 'that strict rules of law, however necessary to a well-ordered society, must be applied with sensitive and tact so that the spirit of the law is not sacrificed unnecessarily to the letter (Posner 2009:96).

\section{MeTHODS}

This study is a descriptive qualitative one, for it will describe and critically analyze the trial scene of The Merchant of Venice. Various theories of critical discourse analysis will be applied to reveal the social and verbal interaction between Jews and Christians in the play, specifically for the trial scene. Another method will be used-critical discourse analysis which is concerned with the relationship between language and power and which is accordingly a special approach in discourse analysis that focuses on the discursive conditions, components and consequences of power. Functional comparison will be in line which is the function of law and which lies in responding to social problems and that all societies face in essence the same problems. This makes it possible to compare legal institutions, even if they display different doctrinal structures, as long as they fulfill the same function, because in this case they are functionally equivalent.

\section{FINDINGS}

On the basis of discussion the findings are as follows; Shakespeare had clear knowledge of Venice as a social and economical state for writing The Merchant of Venice; he was aware of geographical segregation of the Jews and even described everything so impressively and vividly that one has the feeling that Shakespeare might have visited Venice. The other important fact is that he had decent knowledge of the Venetian legal system on behalf of the accessibility to many books and stories about very famous city. Thus the current article will be discussed in line with the existing venetian legal system, civil and criminal procedural laws that were held in the venetian courts and were part of the existed legal system.

\section{DISCUSSION}

When discussing the trial scene of the play it is very important to make a comparative analysis on the basis of an alien and a resident, as Portia enters the Venetian court-room to defend Antonio, and asks: 'Which is the merchant here and which the Jew?' (4.1.70), she implies that the pair is prima facie indistinguishable and infers that both are absolutely equal before the tribunal of Venetian justice. Here it's worth mentioning Gaetano Cozzi who stated that the resistance to technical legal argument meant that Venetian justice was based in equity rather than law. As the ambassador of Parma stated in 1590, the Venetians believed "one should not aim at what the laws say, but what a certain equity and natural reason dictate". Yet from the Fourth Lateran Council in 1215, Jews throughout Christendom had to be 'distinguishable' from Christians; and as stated in my article "Alienage Issues in The Merchant of Venice", early modern reports on the Venetian Jews all describe the fact that they were required to wear some distinguishing dress or headgear.

Act Four opens with the famous trial scene, which contrasts "the quality of mercy" with Shylock's demand for "judgment." The Duke tells Antonio that he can't save him; Antonio and Bassanio slander Shylock and then offer him double his bond. Proud and angry, he refuses this offer. Portia enters, disguised as Balthasar, and delivers the famous "quality of mercy" speech (4.1.184-205). When this does not move Shylock, she outwits him by demanding the absolute letter of the law:

This bond doth give thee here no jot of blood.

The words expressly are "a pound of flesh."

Take then thy bond, take thou thy pound of flesh,

But in the cutting of it if thou dost shed

One drop of Christian blood, thy lands and goods

Are, by the laws of Venice, confiscate. (4.1.306-11)

In fact, justice and fairness (morality) are not synonymous. Although the concept of justice and fairness at first sight may seem the same and there is no reason to distinguish them, the fundamental idea in the concept of justice is fairness. When Shylock sees that he has been tricked, he says he will take the Christians' second offer, but Portia stops him: "Soft. The Jew shall have all justice" (320-21). 
Within a short time, they confiscate his goods and sentence him to death if he cuts "more or less than a just pound" (326-27); when he refuses this gambit, they strip him even of the principal of the loan. Next, Portia cites a law against alien sedition that allows them to strip him of all his goods. A half is to go to the injured party-Antonio - and the other half is for the state. Antonio then begs the court:

To quit the fine for one half of his goods,

I am content, so he will let me have

The other half in use, to render it,

Upon his death, unto the gentleman

That lately stole his daughter. (381-85)

Portia resolves to protect Antonio from the bond's penalty by paying Shylock many times the principle,

"Before a friend of this description

Shall lose a hair through Bassanio's fault" (3.2.299-300).

When she understands that Shylock will not allow the monetary satisfaction of his bond, Portia develops a strategy intended to defeat Shylock. Here the concept of justice is very important, as we have considered that the bond is void. ${ }^{2}$ However, this defeat requires that she engage in an elaborate fraud - in her words, the "device" (3.4.81) - upon the Duke of Venice and others at court. This fraud undermines any justice or law available in court, as Portia has predetermined Shylock's fate; the Venetian courts become simply the forum for Shylock's undoing. To insert herself into the operation of the court, Portia must conceal her identity, and sends to her respected cousin, Bellario, for the garments typically worn by a Doctor of Laws. These garments serve to efface both her gender and her sympathies to the debtor Antonio. It is interesting to note that, in rehearsing her transition from woman to man, Portia identifies the most characteristic male trait as the 'telling of quaint lies' (3.4.69). While the lies rehearsed are those of a boy and, as such, not significant, the suggestion is that dissembling defines the male character. By obscuring her gender, Portia perpetrates the first lie, an ironic and necessary step in her entry into the exclusively male court. Bassanio's soliloquy before the caskets is telling, and foreshadows Portia's double role in court. As Bassanio begins to analyze the three caskets that will determine whether he has won Portia's hand in marriage, he speculates as to the meaning of their adornments:

So may the outward shows be least themselves -

The world is still deceiv'd with ornament.

In law, what plea so tainted and corrupt

But, being season' $d$ with a gracious voice,

Obscures the show of evil? (3.2.73-77)

Just as the ornamentation of the gold and silver caskets conceals the suitor's failure in the loss of Portia, so do Portia's garments conceal the evil of her bias. The popularity of Portia's overly legalistic reading of the bond becomes the "ornament" with which her "tainted and corrupt" judgment is obscured.

In itself, of course, such business interference may be unfair, even unethical, but it is not criminal, and would certainly not incur the death penalty. Salerio thinks the Doge will inevitably set the contract aside, since it is so clearly unreasonable and disproportionate; but as Antonio points out, more is at stake here than his own life and liberty:

SALERIO. I am sure the Duke Will never grant this forfeiture to hold.

ANTONIO. The Duke cannot deny the course of law;

For the commodity that strangers have

With us in Venice, if it be denied,

'Twill much impeach the justice of the state,

\footnotetext{
${ }^{2}$ See Karapetyan T.S. "Legal Interpretations of Shylock's Bond”, International Journal of Humanities, Social Sciences and Educati on, Volume 6, Issue 8, August 2019, ISSN 2349-0373 (Print) \& ISSN 2349-0381 (Online) http://dx.doi.org/10.20431/2349-0381.0608009.
} 
Since that the trade and the profit of the city

Consisteth of all nations. (3.4.26-31)

In this passage it demonstrates judicial and commercial manifesto for Venice, as law played a great role in Serenissima, because of 'the profit of the state, Since that the trade and the profit of the city Consisteth of all nations.' The very basis of the city's survival, let alone its wealth and prosperity, is international trade. It is in the best interests of that international trade that members of other nations should be able to stay and practice their business safely and unhindered: Nick Potter calls this 'the commodity that "strangers" have to promote the circulation of commodities'. If the Doge were to show manifestly unfair preference to a Christian Venetian, like Antonio mentions, then the justice of the state would be compromised, 'impeached', revealed as a shame, and the Venetian economy would suffer in consequence. In terms of commercial law and contract, Shylock's position is, at this point in the play, unassailable and protected. It is indeed the principle of legal equality, equity, constitutionally guaranteed to all citizens of Venice irrespective of race, color or creed, that enables Shylock to pursue his barbaric suit as far as he does. It is, as Nick Potter pointed out, a 'cruel paradox' that the laws of Venice permit equally, to all individual citizens, freedoms which can then be used to deprive other citizens of that same freedom, or even of life itself. As Thomas notes, the condition of 'libertee' stretches even to those who 'beleeuest in the diuell' ... What happens when the guarantee of 'libertee' protects those who want to deprive others of their 'libertee'?

In the trial scene, Portia refers to the suit as 'strange', a word that combines the meanings of unusual, disturbing and alien. But the equity of Venetian law appears (initially at least) to protect the 'stranger', the alien from the first sight, even in the pursuit of a manifestly 'strange' suit. Notwithstanding the idea of Shylock's status as an alien, which becomes much more important later in the trial, Portia in her guise as a lawyer is careful to maintain the semblance that she views the combatants with an impartial eye, seeing not a Christian merchant and a Jewish usurer, but two individuals who are wholly equal before the law.

The Dodge, as presiding judge does not at first sight seem quite so even-handed, like Portia did, when she entered into court, since he refers to the respondent by name ('What, is Antonio here?') and to the plaintiff as 'the Jew' ('Go one, and call the Jew into the court') where we can notice diversity, biases attitude towards the participants of the trial. He also deploys the loaded word 'strange', characterizing Shylock's behavior as alien, in addition to peculiar:

Shylock, the world thinks, and I think so too,

That thou but lead'st this fashion of thy malice

To the last hour of act, and then, 'tis thought

Thou'lt show thy mercy and remorse, more strange

Than is thy strange apparent cruelty. (4.1.17-21)

The Doge invites Shylock to renounce his position as a 'stranger', and to enter the moral consensus of Christian Venice. Here it's proper to go back to Gaetano Cozzi's statement on the notion of equity in the essence of resistance to technical legal argument meant that Venetian justice was based in equity rather than law. The closing line of the Doge's appeal contains a decisive pun:

And where thou now exacts the penalty, -

Which is a proud of this poor merchant's flesh.

Thou wilt not only loose the forfeiture

But, touch'd with human gentleness and love,

Forgive a moiety of the principal,

Glancing an eye of pity on his losses,

That have of late so huddled on his back,

Enow to press a royal merchant down

And pluck commiseration of his state

From stubborn Turks, and Tartars, never train'd 
To offices of tender courtesy.

We all expect a gentle answer, Jew. (4.1.23-34)

The Jew is challenged to give not just a 'merciful' but a Christian answer to the court's appeal. But here it's useful to state that Christian answer is equal to the concept of equity, as in its broadest sense, equity is fairness. But as a legal system, it is a body of law that addresses the concerns that fall outside of the jurisdiction of law. Another point is important here; morality. Of course, law is essentially a set of rules and principles created and enforced by the state whereas morals are a set of beliefs, values and principles and behavior standards which are enforced and created by society. But Shylock does not make the trial into a clash of religions, but the Christian characters deliberately do, as in Christianity equity is the quality of being fair and impartial. When Shylock is asked to subscribe Christian values, the discourse can be read as a reminder of his unequal cultural status. 'How shall thou hope for mercy', asks the Duke, 'rendering none?' Shylock's reply - 'What judgment shall I dread, doing no wrong?' - maintains the legal terminology, but seems to polarize Jewish straight law against Christian forgiveness, an opposition prominent in the later Christian gospels, and thereby to accede to the transfer of the question from the realm of justice to that of belief.

The Duke is offering Shylock an unacceptable Christian solution to the problem as mercy is conceived of as the dominant value of Christianity. In addition the Duke shows a sensitivity to Antonio's losses that is not extended to Shylock's; and urges the usurer to transgress his own commercial ethics by cancelling the loan altogether. Shylock ignores religion and adheres tenaciously to the validity of his contract, asserting his rights to claim restitution from the defaulting debtor, and consulting the document itself (the 'bond') on more than one occasion. The contract was freely entered into by Antonio, and Venice protects Shylock's rights as the injured party.

SHYLOCK: I have possessed your Grace of what I purpose,

And by our holy Sabaoth have I sworn

To have the due and forfeit of my bond.

If you deny it, let the danger light

Upon your charter and your city's freedom! (4.1.35-9)

All he asks from the court is that his bond be upheld which is his legal strategy, and which it is an intelligent one, according to the judicial context. Though he is proceeding on the basis of a law that offers universal protection, Shylock does so from the position of a 'stranger' rather than that of a citizen of Venice. And here it's worth recalling the lines where Salerio thinks the Doge will inevitably set the contract aside, since it is so clearly unreasonable and disproportionate; but as Antonio points out, more is at stake here than his own life and liberty as judicial and commercial manifesto for Venice, as law played a great role in Venice, because of 'the profit of the state, Since that the trade and the profit of the city Consisteth of all nations.'

If you deny it, let the danger light

Upon your charter and your city's freedom. (4.1.37-8)

...If you deny me, fie upon your law:

There is no force in the decrees of Venice.

I stand for judgment. Answer: shall I have it? (4.1.101-3)

Actually, Shylock speaks not of his own charter, his own city's freedom or law, but of someone else's: your charter, the freedom of your city, your law. In fact, the Jew is fully aware that this is not a simple application of the law to a contractual dispute, as it would be if the parties were fully equal Venetian citizens, but a test case which stretches the tolerance of the law to its full extent; he indirectly threatens the court. A Jew is claiming legal compensation from a Christian, so the demand for universal equality is launched from a position of cultural subjugation that in turn denies the equality claimed. Despite his continual iteration of the legal argument - the bond has been breached and the penalty is forfeit - this is a Jew seeking redress from a Christian court. Here it's worth mentioning my article "Legal Interpretation of Shylock's Bond" where it is stated that such types of bonds really existed in Italy during this period. 
When there is no other way for the court and the lawyer in terms of equity and morality, on the one hand, and on the other hand, the Venetian law can't be breached, as it's a matter of authority for Venetian justice system, Portia leads Shylock almost to the point of Antonio's death, with her assurance that his suit is legally unassailable, and then with her famous injunction to pause - 'Tarry a little' - produces a devastating dramatic reversal, which sets the action spinning off in a completely opposite direction. The law still gives Shylock the right to exact his penalty: but other statutes render the exaction of the penalty a criminal offence. These laws, unlike the law protecting the cosmopolitan freedom of commercial exchange, are designed to protect the Venetian citizen against the hostile actions of racial and cultural outsiders:

Take then thy bond, take thou thy pound of flesh,

But in the cutting it, if thou dost shed

One drop of Christian blood, thy lands and goods

Are, by the laws of Venice confiscate

Unto the state of Venice. (4.1.304-8)

Since there could be no flesh without blood, in recognizing the right to take flesh, the Jew legally would have had all incidental powers necessary to the full enjoyment of the affirmative legal right and could draw the blood, as a necessary incident of the right to take the flesh, for without it, his right could not be exercised. It was axiomatic, at common law, that where one had a legal right, he had all the remedies necessary to a full enjoyment of that right, for otherwise the right itself would be without avail (White 2002: 131-132).

The subsequent directive to cut off no more than 'a just pound' seems to be part of the same law protecting Christian flesh against the non-Christian enemy. To subvert the law that treats all men equally, Portia invokes a law designed explicitly to treat them unequally, but here preference must be given to the equity which is an inseparable part of the venetian legal system. If the situation were reversed, the Jew would not by the same law be protected against the Christian. Finally, Portia reveals her bottom-line defense of Antonio, which is a conspiracy law targeted directly at the outsider:

It is enacted in the laws of Venice,

If it be proved against an alien

That by direct or indirect attempts

He seek the life of any citizen,

The party 'gainst the which he doth contrive

Shall seize one half his goods, the other half

Comes to the privy coffer of the state,

And the offender's life lies in the mercy

Of the duke only, 'gainst all other voice.

In which predicament I say, thou stand'st;

For it appears by manifest proceeding

That indirectly, and directly too,

Thou hast contrived against the very life

Of the defendant; and thou hast incurred

The danger formerly by me rehearsed. (4.1.344-57)

Despite the many implications of her ruling, Portia ultimately acts to uphold and enforce Shylock's bond. She converts Shylock's demand for legal enforcement into a criminal attempt on Antonio's life. This nonsensical juridical conclusion suggests that the "law" repeatedly demanded by Shylock is infinitely plastic and exists to be manipulated by a partial - and quite literally false - judiciary. As such, Portia, through Shylock's condemnation, implicates the very laws and legal procedures of 
Venice. While nominally still inviolate, Venetian law becomes no more than the convenient instrument of Shylock's demise, loosing of the trial, and the certainty desired by all with a stake in its commerce - including the Duke, Antonio, Shylock, and Portia - is compromised.

\section{CONCLUSION}

The 'trial' thus begins with a deadlock of competing economic interests, in which there is a valid bond, and in which the protection afforded to contract by Venetian law binds the judicial authorities in a helpless subjection to the most literal legalism. Portia, too, recognizes that the law must respect and enforce such private commercial agreements or risk losing the confidence of its merchants for want of certainty and predictability. Shylock understands this and forces the court to enforce his penalty. Indeed, that Shylock is no stranger to commercial transactions strongly suggests that he understood that the bond would be viewed by the law not as merely "merry sport" but as binding.

Of course, what Portia says is that the penalties which Shylock risks are laid down "by the laws of Venice" (4.1.307), and this may seem to scotch the idea that Jewish law might have any application here. She implies that the pair is prima facie indistinguishable and infers that both are absolutely equal before the tribunal of Venetian justice. Gaetano Cozzi stated that the resistance to technical legal argument meant that Venetian justice was based in equity rather than law.

Another important thing is the interrelation of justice and fairness (morality) which are not simply synonymous. The concept of justice and fairness at first sight may seem the same and there is no reason to distinguish them, but the fundamental idea in the concept of justice is fairness.

Venice lived and traded under a rule of written law interpreted by elected councils and judges and enforced by an elaborate bureaucracy. Law is a judicial and commercial manifesto for Metropolitan City of Venice, as it played a great role for Serenissima, because of the profit of the state. The very basis of the city's survival, let alone its wealth and prosperity, is international trade. It is in the best interests of that international trade that members of other nations should be able to stay and practice their business safely and unhindered.

\section{REFERENCES}

[1] Blanchard, J. (2009). Contesting Constancy in the Merchant of Venice. Renascence, 61(4), 209-220.

[2] Bodin J., (2009). Six books of the Commonwealth, Oxford, e- text, Ch. 6.764, ISBN 1438288700.

[3] Chambers D., Pullan B., (2001).Venice. A Documentary History, 1450-1630, University of Toronto Press.

[4] Cozzi G. (1982). Repubblica di Venezia e stati italiani: politica, e giustizia dal secolo XVI al secolo XVIII, Torino, Einaudi, 1982.

[5] G. Cozzi : Ambiente veneziano, ambiente Veneto. Governanti e governati nel dominio di qua dal Mincio nei secoli XV-XVIII", in G. Arnaldi and M. Pastore Stocchi (eds.), Storia della cultura Veneta, 4/II, il Seicento (Vicenza: Neri Pozza, 1984).

[6] Cunningham K. (2002). Fugitive Forms: Imagining the Realm, in Imaginary Betrayals: Subjectivity and the Discourses of Treason in Early Modern England (Philadelphia, PA: University of Pennsylvania Press.

[7] Deng, W., \& Wu, Y. (2013). The New Exploration to the Merchant of Venice. Theory and Practice in Language Studies, 3(9), 1624-1629.

[8] Elton W. R., (2000) Shakespeare's Troilus and Cressida and the Inns of Court Revels (Aldershot: Ashgate, Phillips, Shakespeare and the Lawyers, pp. 105-07, quoting Sir Frederick Pollack, "A Note on Shylock v. Antonio," Law Quarterly Review30 (1914), 175.)

[9] Holderness, G., Turner, J., Potter, Nick, (1987): Shakespeare: the Play of History, Palgrave Macmillan, ISBN 978-1-349-19069-0.

[10] Keeton ,G.W., Shakespeare's Legal and Political Background (London: Sir Isaac Pitman \& Sons, 1967) at 145.

[11] Posner A., (2009), Law and Literature, p. 592, ISBN-13: 978-0674032460.

[12] Pullan B., Gaetano Cozzi (1922-2001), Renaissance Studies, Vol. 16, No. 4 (December 2002), pp. 561565 .

[13] Ruggiero G. Law and punishment in early Renaissance Venice,69 J. Crim. L. \& Criminology 243 (1978).

[14] Shakespeare, W. (1989), the Complete Works of William Shakespeare. New York: Barnes \& Noble.

[15] Shaw J. (2006), the Justice in Venice, the British Academy, Oxford University Press, ISBN 0-19-726377-1.

[16] Vianello M., L'avvocato in commedia; Goldoni e l'autobiografia, Studi Veneziani, n.s. 22, 1991. 
[17] White E. J. (2002). Commentaries on the Law in Shakespeare, University Press of the Pacific, ISBN10: 1410203514, p. 584.

\section{AUTHORS' BIOGRAPHY}

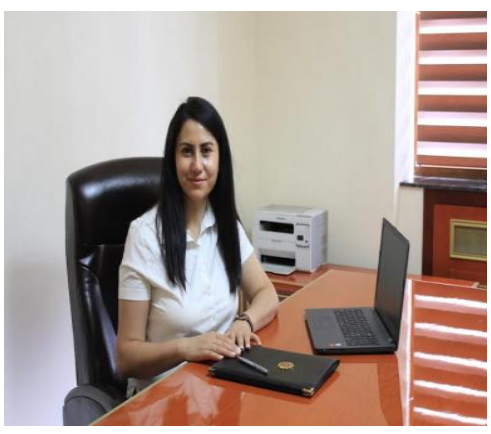

Dr. Tatevik S. Karapetyan, is a specialist in Comparative Literature. The focus of her research work at the Yerevan State University was centered round the European languages and Foreign Literature. During master"s years she wrote thesis on the "New poetical movements in English and Anglo-American Literature in 20th century", after which she completed her $\mathrm{PhD}$ in philology namely 20th century Anglo-American drama in 2014 with the following doctoral thesis "Social and individual conflicts in the plays of Eugene O"Neill". She has been appointed as a literature expert for the scientific council of foreign and comparative literature in the Currently, she works as an expert at The National Center for Professional Education Quality Assurance Foundation (ANQA). She is also a Postdoc Researcher at the Branca Center in Fondazione Giorgio Cini and her main research activities are concerned with law and literature, economy and literature, social relations and literature. She is the Head of the Department of Humanitarian Subjects at the University of Traditional Medicine, Associate Professor and Associate Professor of English in Armenian State Institute of Physical Culture and Sport, The French University in Armenia.

Citation: Tatevik S. Karapetyan, "Procedural Law in the Merchant of Venice" International Journal on Studies in English Language and Literature (IJSELL), vol 8, no. 9, 2020, pp. 22-31. doi: https://doi.org/10.20431/2347-3134.0809003.

Copyright: (C) 2020 Authors. This is an open-access article distributed under the terms of the Creative Commons Attribution License, which permits unrestricted use, distribution, and reproduction in any medium, provided the original author and source are credited. 